\title{
Evaluation of Low Back Pain in Field Hockey Players
}

\author{
Mustafa Gümüşs ${ }^{1}$ Tevfik Cem Akalin ${ }^{1}$, Hüseyin Hakan Kudak ${ }^{1}$, Resul Çekin², Mustafa Ertuğrul Çiplak ${ }^{1}$, Bilal Emektar ${ }^{1}$, \\ Geylan Bostan ${ }^{1}$ \\ ${ }^{1}$ Zonguldak Bülent Ecevit University, School of Physical Education and Sports, Zonguldak, Turkey \\ ${ }^{2}$ Amasya University, Faculty of Education, Physical Education and Sport Teacher Department, Amasya, Turkey \\ Correspondence: Tevfik Cem Akalin, Zonguldak Bülent Ecevit University, School of Physical Education and Sports, \\ Zonguldak, Turkey.
}

Received: September 6, 2018

Accepted: October 18, 2018

Online Published: October 22, 2018

doi:10.11114/jets.v6i12.3605

URL: https://doi.org/10.11114/jets.v6i12.3605

\begin{abstract}
It is aimed to evaluate the conditions of low back pain in field hockey players. 196 field hockey players and 170 of similar age range university students participated voluntarily. Participants demographic characteristics, low back pain history, and risk factors were questioned, Biering Sorensen Test (BST) was administered to test the strength and endurance of the back extensors. The data were evaluated in the SPSS 20 for Windows package program. Student's T-Test, ANOVA Test, Post-Hoc Bonferroni Test and Pearson Correlation Analysis were used for statistical analysis. Analysis results were evaluated at $95 \%$ confidence interval, $\mathrm{p}<0.05$ was accepted as statistically significant difference. The lifelong prevalence was $82 \%$ in the athletes group and $66 \%$ in the control group; however, there was no statistically significant difference between the two groups $(\mathrm{p}=0.524)$. In terms of frequency of back pain (VAS) in the last three months, there was a significant difference between the athletes and the control groups $(p<0.05)$. The BST average duration of national athletes was $95.2 \pm 18.5 \mathrm{sec}$ of super league athletes was $101.3 \pm 15.4 \mathrm{sec}$, and of control group was $110.6 \pm 16.8 \mathrm{sec}$. A statistically significant difference was found between the national athletes and the control group according to BST scores $(\mathrm{p}=0.001)$. Compared to national athletes, super league athletes, and control groups, it has been found that being a Field Hockey National Players pose much more risk for low back pain. It was found that low back pain was widespread amongst athletes, and it is seen at a higher rate in national field hockey players.
\end{abstract}

Keywords: field hockey, Biering Sorensen test, back pain

\section{Introduction}

Low back pain is defined as the pain felt between the lower gluteal folds and the costal margin (Yüksel \& Tarhan, 2014). Low back pain (LBP) is well documented as an extremely common health problem (Hoy et al. 2014). 18\% of the world's population may be experiencing LBP and 38\% of people will experience LBP over the course of 1 year (Hoy et al. 2012). In western countries, which have put the lifetime and point prevalence of back pain in adolescents is within the range of 56-59\% (Weisel 2002). Low back pain is the fifth most common cause of consulting a doctor in the United States (Deyo et al., 2006). In Turkey, every year, 8-15.8\% of emergency room admittances are reported to be due to low back pain (Yüksel \& Tarhan, 2014).

Prevalence of LBP among young elite athletes compared to the general age-related population was 3-5 times higher. (Van Hilst et al. 2015). According the literature review, the prevalence of LBP in athletes has been reported from $1 \%$ to $30 \%$, and also, 10-15\% of all sport injuries are low back injuries (Mortazavi et al., 2015). It is thought that being physically active will reduce the risk of low back pain, however, being too active might increase the risk of LBP according to the U-shaped exposure response curve between physical activity and LBP (Van Hilst et al. 2015). The relationship between activity level and back pain reportedly follow a U-shaped curve (Heneweer et al. 2011).

In sports such as hockey, players often struggle to use their bodies in this position, and moreover, they are exposed to high pressures in this way, causing them to live LBP quite often. The authors contend that the prevalence of flexed lumbar postures that accompany participation in field hockey renders the athletes susceptible to injuries of the lumbar spine at a rate significantly greater than the non-field hockey playing population (Haydt et al. 2012).

The crouched playing position in hockey combined with side flexion and rotation may be contributing factors in the high incidence of low back problems (Sherker \& Cassell, 2002). It is determined that low back pain is the most 
common complaint, in sports like golf too (Reinhardt, 2013). The result of this is shown as activities that require hip rotation such as a golf swing or a racquet sport could result in an increased and out-of-sync lumbo-pelvic motion (Reinhardt, 2013). Sustained forward flexed lumbar postures when coupled with rotation have been demonstrated to be stressful to structures of the lumbar spine (Haydt et al. 2012). In field hockey, playing and dribbling the ball are usually executed in a position of spinal flexion. As a result of participation in field hockey injuries to the lumbar spine have been reported in epidemiological studies (Rozan et al. 2016). The rates and types of injuries experienced by field hockey players and reported that the low back was the most commonly injured region (Murtaugh 2001).

Hockey is played in 132 countries and is the second most popular team sport after soccer (Sherker \& Cassell 2002). Although hockey is a very common sport, the risk factors for hockey players and the number of studies examining the LBP prevalence, are limited. It is important to determine the risk factors that cause back pain, which is the most common injury in Field Hockey athletes. Because the onset of LBP leads to reduced performance levels (Van Hilst et al., 2015). In this study, it was aimed to determine the frequency of back pain with BST in field hockey players and compare it with general population, and to determine the effect of risk factors on low back pain.

\section{Method}

There were 366 men in the study, including the Field Hockey Men's National Team ( $n=36)$, the players in the Open Hockey Super League $(\mathrm{n}=160)$, and the control group $(\mathrm{n}=170)$ of similar age range university students. In the control group that was in the study; demographic characteristics, low back pain history, and low back pain risk factors were questioned, and 'Biering Sorensen Test' was administered which tests the strength and endurance of the back extensors. With this test, the static endurance of the body extensors was evaluated. It measures how long (to a maximum of 240 seconds) the participant can keep the unsupported trunk (from the anterior iliac crests level up) horizontal while lying prone on a plinth with their hands held by their sides. The test procedure was explained and demonstrated to the participants at inclusion. The participant laid on the examination table in the prone position with the upper edge of the iliac crests aligned with the edge of the table. The lower body was fixed to the table by three non-elastic straps, located around the pelvis and ankles respectively with a towel used to relieve stress on the ankle joint. With the arms held along the sides touching the body, the participant was asked to isometrically maintain the upper body in a horizontal position. They were asked to hold the horizontal position, till they cannot anymore. The timing was recorded. The data were evaluated after they are transferred to the SPSS 20 for Windows package program. Average values are shown as "arithmetic average \pm standard deviation". In the statistical analysis of the data; Student's' T-Test, ANOVA Test, Post-Hoc Bonferroni Test and Pearson Correlation Analysis were used. Analysis results were evaluated at 95\% confidence interval, $\mathrm{p}<0.05$ was accepted as statistically significant difference.

\section{Results}

Table 1. Some demographic characteristics of participants and evaluations on their frequency of sports

\begin{tabular}{l|c|c|c}
\hline \multirow{2}{*}{ Study Group } & $\begin{array}{c}\text { Field Hockey National } \\
\text { Team }(\mathrm{n}=36)\end{array}$ & $\begin{array}{c}\text { Open Field Hockey } \\
\text { Super League (n=160) }\end{array}$ & Control Group (n=170) \\
\cline { 2 - 4 } & Average \pm SD & Average \pm SD & Average \pm SD \\
\hline Age (years) & $19,52 \pm 1,89$ & $19,18 \pm 2,14$ & $20,63 \pm 2,25$ \\
\hline Height (cm) & $168,26 \pm 6,63$ & $167,35 \pm 3,45$ & $165,59 \pm 4,86$ \\
\hline Weight (kg) & $74,05 \pm 11,54$ & $76,47 \pm 8,12$ & $80,75 \pm 6,38$ \\
\hline Training (years) & $8,54 \pm 2,51$ & $5,36 \pm 1,85$ & - \\
\hline Training (days/week) & $4,84 \pm 0,82$ & $2,91 \pm 1,14$ & - \\
\hline Training (hour/days) & $2,28 \pm 0,56$ & $1,43 \pm 0,85$ & - \\
\hline National player (years) & $5,48 \pm 3,64$ & - & - \\
\hline
\end{tabular}

Table 2. Frequency of LBP of Participants

\begin{tabular}{|c|c|c|c|c|c|c|}
\hline \multirow{2}{*}{\multicolumn{2}{|c|}{ Study Group }} & \multicolumn{4}{|c|}{ Lifelong Prevalence } & \multirow[b]{2}{*}{$\mathbf{p}$} \\
\hline & & \multicolumn{2}{|c|}{ Yes } & \multicolumn{2}{|c|}{ No } & \\
\hline \multirow{2}{*}{ Athlete's Group } & National Team $(n=36)$ & $\mathbf{n = 3 4}(\% 94,44)$ & $\mathbf{n}=\mathbf{1 6 1}(\% 82.14)$ & $\begin{array}{c}\mathbf{n}=\mathbf{2} \\
(\% 5,56)\end{array}$ & $\mathbf{n}=\mathbf{3 5}(\% 17.86)$ & \multirow{3}{*}{0,524} \\
\hline & Super League $(n=160)$ & $\mathbf{n}=\mathbf{1 2 7}(\% 79,37)$ & & $\mathbf{n}=\mathbf{3 3}(\% 20,63)$ & & \\
\hline Control $(n=170)$ & & \multicolumn{2}{|c|}{$\mathbf{n}=112(\% 65.88)$} & \multicolumn{2}{|c|}{$\mathbf{n}=\mathbf{5 8}(\% 34.12)$} & \\
\hline
\end{tabular}

In our study the lifelong prevalence was $82 \%$ in the athletes group and $66 \%$ in the control group, however, there was no statistically significant difference between the two groups $(\mathrm{p}=0.524)$. In terms of frequency of back pain in the last three 
months and VAS scores, there was a significant difference between the athletes and the control groups, $(\mathrm{p}<0.05)$.

Table 3. Comparison of frequency of low back pain

\begin{tabular}{l|c|c|c|c}
\hline \multicolumn{1}{c|}{ Study Group } & $\begin{array}{c}\text { Biering Sorensen } \\
\text { Test }(\mathrm{sec})\end{array}$ & National Team & League & Control \\
\hline National Team & $95,2 \pm 18,5$ & - & & \\
\hline League & $101,3 \pm 15,4$ & $\mathrm{p}=0,135$ & - & - \\
\hline Control & $110,6 \pm 16,8$ & $\mathbf{p}=\mathbf{0 , 0 0 1}$ & $\mathrm{p}=0,085$ & \\
\hline
\end{tabular}

There was statistically significant difference in between groups according to Biering Sorensen Test scores (p<0.05). When national team was compared to the control group, statistically, significant difference was found $(\mathrm{p}<0.05)$.

\section{Discussion}

In our study the lifelong prevalence was $82 \%$ in the athletes group and $66 \%$ in the control group, however, there was no statistically significant difference between the two groups $(\mathrm{p}=0.524)$. In terms of frequency of back pain in the last three months and VAS scores, there was a significant difference between the athletes and the control groups, $(\mathrm{p}<0.05)$. Murtaugh (2001) found a 59\% back pain rate in high school, university, and national level female field hockey players $(n=158)$ with age average of 19.8 years, and an average athletic experience of 6.8 years, and stated that low back pain is the most common pain. In his study, Haydt et al., (2012), female NCAA Division III FH players ( $\mathrm{n}=90)$ ranging in age from 18-24 years old who participated in the 2008 season were surveyed in regards to the incidence of LBP. The descriptive data illustrates similarities in the incidence of low back pain in the female field hockey player group compared to the control group. The average onset age of low back pain for the controls and the field hockey group was $16.45+/-2.12$ years old and $16.23+/-1.80$ years old respectively. The incidence of low back pain in the control group was 55\% (54/98) and 56\% (50/90) in the field hockey group respectively. Van Hilst et al. (2015) calculated the overall 12-month prevalence of LBP in elite field hockey players aged 14-25, as $60 \%$. In our results, the rate of low back pain is higher than other studies. This difference can be explained by the fact that the participants are national athletes and that national athletes are exposed to more intense training and strain. Our idea was supported by seeing $94 \%$ of national athletes and only $40 \%$ of super league players have the history of back pain in our results, and the founding of Fett et al., (2017) with their control group of 1114 elite athletes and 166 physically active students with an average age of 20.9 years \pm 4.8 years, as the lifetime prevalence of back pain is $88.5 \%$. Again in the same study, they found that the 12 -month prevalence of elite athletes was $81.1 \%$ and the 3 -month prevalence was $68.3 \%$. 12-month and 3-month prevalence in elite athletes were significantly higher than in the control group. The studies usually have low back pain scores of 12 months or lifetime. Only Fett et al., 2017 work has 3-month LBP scores, however, even if he has elite field hockey players in his study, this average is the proportion of elite athletes in many sports branches. Although this may limit the discussion, even though studies mentioned before has longer duration of 3 months, the rate of low back pain in our study is higher than in other studies. The reason for this may be that the national players in our study group have high training loads to achieve high performance levels. The low rate of back pain in the study of Haydt et al. can be explained by the participants who are in the in the 3rd league, and possibly have less training and match loads. Many factors such as kind of sport, gender, training intensity, frequency and technique affect the rate of low back pain in athletes (Dreisinger \& Nelson 1996; Kujala et al., 1999)

The BST average duration of national athletes was $95.2 \pm 18.5 \mathrm{sec}$, of super league athletes was $101.3 \pm 15.4 \mathrm{sec}$, and of control group was $110.6 \pm 16.8 \mathrm{sec}$. A statistically significant difference was found between the national athletes and the control group according to BST scores $(\mathrm{p}=0.001)$. Compared to national athletes, super league athletes, and control groups, it has been found that being a Field Hockey National Players pose much more risk for low back pain. Similarly, Van Hilst et al. (2015) found that the ratio of LBP in elite field hockey was 3-5 times higher than in the general population.

As a result, low back pain is an important and common cause of missing games in athletes (Delvaux \& Lysens 2002; Erhan et al., 2009), and is a common problem for sportsmen. It can be said that field hockey athletes have higher rates than other athletes according to their league categories. In this case, early identification of athletes by clinicians, especially those with high risk of low back pain, and in the case of sports such as hockey which constitutes a high risk due to the structure of the low back pain formation, it is mentioned that preventive special programs for the players, training needs to be done. For athletes who consult clinicians for low back pain; conditions that increase back pain, such as the character, location, spread, onset and time of the pain should be well recorded. Determining the onset, timing, and early detection of low back pain problems, and therefore the application of preventive measures and treatments, can reduce the loss of efficiency of the athletes. It has been determined that low back pain, especially in the National Field Hockey athletes, is higher, and that precautions should be taken, given that low back pain leads to significant loss of exercise and sportive efficiency. In assessing the pain it is supported that, the BST, which has proven its validity and reliability in the literature, is a cheap, at the same time simple, and useful clinical test which may be used for those who have or have the possibility to have a low back pain. 


\section{Acknowledgments}

Congress: This manuscript has been presented in 13th International Sports Sciences Congress, oral presentation in Konya/Turkey, 07-09 November, 2014.

\section{References}

Delvaux, K., \& Lysens, R. (2002). Lumbosacral pain in an athlete. Clin. Sports Med., 21, 93-103.

Deyo, R. A., Mirza, S. K., \& Martin, B. I. (2006). Back pain prevalence and visit rates: estimates from US national surveys, 2002. Spine, 31, 2724-2727. https://doi.org/10.1097/01.brs.0000244618.06877.cd

Dreisinger, T. E., \& Nelson, B. (1996). Management of back pain in athletes. Sports Med. 21(4), 313-320. https://doi.org/10.2165/00007256-199621040-00006

Erhan, B., Gündüz, B., Üstünel, S., \& Savaş, F. (2009). Low back pain in athletes: common problems and conservative treatment. Medical Journal of Bakırköy, 5(4), 127-131.

Fett, D., Trompeter, K., \& Platen, P. (2017): Back pain in elite sports: A cross-sectional study on 1114 athletes. Plos One. https://doi.org/10.1371/journal.pone.0180130

Haydt, R., Pheasant, S., \& Lawrence, K. (2012). The Incidence of Low Back Pain in NCAA Division III Female Field Hockey Players. International Journal of Sports Physical Therapy, 7(3), 296-305.

Heneweer, H., Staes, F., Aufdemkampe, G., van Rijn, M., \& Vanhees, L. (2011). Physical activity and low back pain: a systematic review of recent literature. Eur Spine J. Jun; 20(6):826-845.

Hoy, D., Bain, C., Williams, G., March, L., Brooks, P., Blyth, F., .. \& Buchbinder, R. (2012). A systematic review of the global prevalence of low back pain. Arthritis Rheum., 64(6), 2028-237. https://doi.org/10.1002/art.34347

Hoy, D., March, L., Brooks, P, et al. (2014). The global burden of low back pain: estimates from the Global Burden of Disease 2010 study. Ann Rheum Dis. 73, 968-974. https://doi.org/10.1136/annrheumdis-2013-204428

Kujala, U. M., Kinnunen, J., Helenius, P., Orava, S., Taavitsainen, M., \& Karaharju, E. (1999). Prolonged low-back pain in young athletes: a prospective case series study of findings and prognosis. Eur. Spine J., 8(6), $480-484$. https://doi.org/10.1007/s005860050209

Mortazavi, J., Zebardast, J., \& Mirzashahi, B. (2015). Low back pain in athletes. Asian Journal of Sports Medicine, 6(2). e24718. https://doi.org/10.5812/asjsm.6(2)2015.24718

Murtaugh, K. (2001). Injury patterns among female field hockey players. Med Sci Sports Exerc., 33, $201-207$. https://doi.org/10.1097/00005768-200102000-00005

Reinhardt, G. (2013). The role of decreased hip IR as a cause of low back pain in a golfer: A Case Report. HSS Journal, 9(3), 278-283. https://doi.org/10.1007/s11420-013-9353-9

Rozan, M., Rouhollahi, V., Rastogi, A., \& Dureha, D. K. (2016). Influence of Physiological Loading on the Lumbar Spine of National Level Athletes in Different Sports. Journal of Human Kinetics, 50, $115-123$. https://doi.org/10.1515/hukin-2015-0148

Sherker, S., \& Cassell, E. (2002). A review of field hockey injuries and countermeasures for prevention. Report No 143. Monash University Accident Research Centre. May 2002, 11-27.

Van Hilst, J., Hilgersom, N. F., Kuilman, M. C., Kuijer, P. P., \& Frings-Dresen, M. H. (2015). Low back pain in young elite field hockey players, football players and speed skaters: Prevalence and risk factors. J. Back Musculoskelet Rehabil. 28(1), 67-73. https://doi.org/10.3233/BMR-140491

Weisel, W. S. (2002). Back pain in adolescents: Raging public health crisis or benign growing pain? The Back Letter; $17(3), 32-34$.

Yüksel, O., \& Tarhan, M. A. (2014). Low back athletes and treatment approaches, Turkish Journal of Sports Medicine, $49,1-13$.

\section{Copyrights}

Copyright for this article is retained by the author(s), with first publication rights granted to the journal.

This is an open-access article distributed under the terms and conditions of the Creative Commons Attribution license which permits unrestricted use, distribution, and reproduction in any medium, provided the original work is properly cited. 